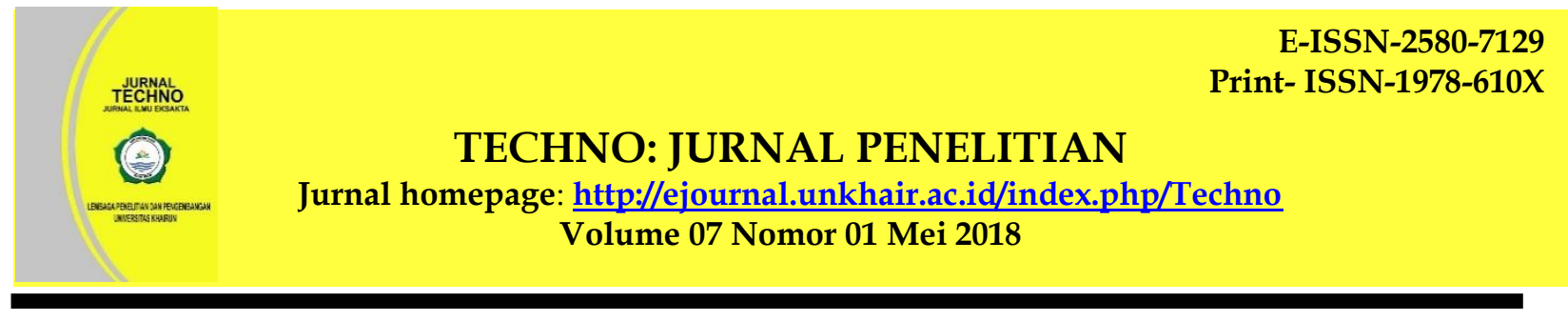

\title{
Sampah Rumah Tangga di Ternate
}

\author{
Bahtiar1 $^{*}$, Zulkifli Ahmad1, Wiyana Pobi² \\ 1Program Studi Pendidikan Biologi Universitas Khairun, Ternate \\ 2Mahasiswa Program Studi Pendidikan Biologi Universitas Khairun, Ternate \\ *Corresponding authors: lafigur@yahoo.co.id \\ Manuscript received: 29-03-2018 Revision accepted: 18-04-2018
}

\begin{abstract}
Abstrak
Jumlah penduduk Kota Ternate 212.997 jiwa, luas wilayah 111,39 km2 dengan kepadatan 1.865,42 jiwa/ km2. Apabila kita menggunaan pendekatan paradigma "sampah sebagai barang berguna" maka jumlah penduduk sebanyak itu menghasilkan volume sampah yang berpotensi untuk dimanfaatkan dan diolah kembali. Terkait kepentingan pengelolaan dan pemanfaatan sampah di Kota Ternate ke depan, maka kedudukan sampah merupakan sebuah potensi. Deskripsi potensi sampah harus diawali dengan pengenalan komposisi dan timbulan sampah yang ada, terutama sampah rumah tangga. Gambaran komposisi akan memberikan informasi tentang komponen yang terdapat dalam buangan padat beserta distribusinya. Timbulan sampah memberikan informasi banyaknya sampah rumah tangga yang dihasilkan. Data timbulan sampah juga diperlukan untuk desain sistem pengelolaan persampahan, seleksi jenis peralatan untuk transportasi sampah dan desain tempat pembuangan sampah.
\end{abstract}

Kata Kunci:, komposisi sampah, rumah tangga, Kota Ternate

\begin{abstract}
The population of Ternate City is 212,997 people, the area of $111.39 \mathrm{~km} 2$ with the density of $1,865.42$ people $/ \mathrm{km}^{2}$. If we use the paradigm approach of "waste as a useful item" then the amount of population as much as it produces the volume of waste that has the potential to be utilized and reprocessed. Related to the management and utilization of waste in Ternate City in the future, the position of waste is a potential. Description of potential waste should be started with the introduction of composition and waste generation, especially household waste. The composition description will provide information on the components contained in solid waste and its distribution. Waste generation provides information on the amount of household waste generated. Waste generation data is also required for the design of waste management systems, the selection of equipment types for waste transport and the design of landfills.
\end{abstract}

Keywords: composition of waste, household, Ternate city

\section{PENDAHULUAN}

Selama ini sampah dikelola dengan konsep buang begitu saja (open dumping), buang bakar (dengan incenerator atau dibakar begitu saja), gali tutup (sanitary landfill), ternyata tidak memberikan solusi yang baik, apalagi jika dilaksanakn tidak disiplin (Widiyatmoko, Purwaningrum, dan Arum, 2014). Penyebab banjir umumnya sampah adalah sampah organik, plastik atau kaleng-kaleng yang sulit terurai. Sampah-sampah jenis ini juga perlu di daur ulang. Dalam konteks inilah, perlu dicari solusi penanganan sampah kota, yang mampu mengeliminir menumpuknya timbunan sampah, sampai mencapai taraf zero waste (Zubair, Nogard, Mahendra \& Asrini, 2011). 
Sampah tidak akan menjadi masalah selama daya tampung alami lingkungan mampu mendaurulang bahan non-organik atau menguraikan bahan organik melalui kegiatan metabolisme mikroba menjadi bahan non organik yang dapat diserap kembali oleh lingkungan tanpa mengganggu keseimbangan alaminya (Widiarti, 2012). Masalahnya, kondisi perkotaan yang padat penduduk dengan lahan sempit, volume sampah setiap hari melampaui daya tampung lingkungan, sehingga menimbulkan gangguan terhadap keseimbangan kualitas lingkungan sampai pada tahap yang tidak dapat lagi ditolerir. Zulkifli (2015) mengemukkan bahwa umumnya onggokan sampah di perkotaan berasal dari sampah rumah tangga.

Tidak semua sampah tidak mempunyai nilai atau guna, sampah memiliki bahan-bahan yang dapat dimanfaatkan. Jenis-jenis sampah yang dapat dimanfaatkan, di antaranya: (1) sampah organik yang memiliki kandungan protein, lemak, karbohidrat, serat, dan nutrient lain, dan kalori yang potensial dijadikan pupuk organik/kompos, dan makanan ternak, (2) sampah plastik terdiri atas berbagai jenis polimer plastik yang berbeda, dapat diolah dan dimanfaatkan kembali, (3) sampah kertas terdiri atas berbagai jenis komponen kertas yang dapat diolah dan dimanfaatkan kembali, dan (4) sampah logam yang terdiri atas berbagai jenis komponen logam yang dapat diolah dan dimanfaatkan kembali. Oleh karena itu, Saat ini, selain menjadi sumber masalah bagi kualitas lingkungan dan kesehatan, sampah juga dapat menjadi lahan pencarian baru bagi sebagian orang.

Ternate adalah salah satu kota yang mengalami pertumbuhan penduduk dan ekonomi yang cukup pesat, telah memicu meningkatnya kegiatan jasa, industri, bisnis dan sebagainya (Akbar, Rengkung dan Warouw, 2014). Sampah merupakan suatu masalah yang sangat mendasar di Ternate. Timbulan sampah di tempat-tempat terbuka dapat menjadi tempat berkembangnya penyakit dan menurunkan kualitas lingkungan. Sampah tersebut juga menjadi penyebab menurunnya estetika kota bila tidak ditangani dengan baik. Produksi sampah di Ternate, kususnya sampah rumah tangga terus meningkat seiring dengan meningkatnya jumlah penduduk. Genagan air saat musim hujan sering disebabkan oleh sampah organik, plastik, kaleng bekas, dan lain-lain yang menyumbat saluran-saluran air.

Jumlah penduduk Kota Ternate 212.997 jiwa, luas wilayah 111,39 km² dengan kepadatan 1.865,42 jiwa per $\mathrm{km}^{2}$ (BPS Kota Ternate, 2016). Penduduk tersebut tersebar pada 7 kecamatan, yaitu Kecamatan Pulau Ternate, Kecamatan Moti, Pulau Batang Dua, Hiri, Ternate Selatan, Ternate Tengah, dan Kecamatan Ternate Utara. Apabila kita menggunaan pendekatan paradigma "sampah sebagai barang berguna" maka jumlah penduduk sebanyak itu menghasilkan volume sampah yang berpotensi untuk dimanfaatkan dan diolah kembali.

Terkait kepentingan pengelolaan dan pemanfaatan sampah di Kota Ternate ke depan, maka kedudukan sampah perlu dilihat sebagai sebuah potensi. Gambaran utuh tentang potensi sampah harus diawali dengan pengenalan komposisi dan timbulan sampah yang ada, terutama sampah rumah tangga. Gambaran komposisi akan memberikan informasi tentang komponen yang terdapat dalam buangan padat beserta distribusinya. Sedang timbulan akan memberikan informasi banyaknya sampah rumah tangga yang dihasilkan. Data timbulan sampah juga diperlukan untuk desain sistem pengelolaan persampahan, seleksi jenis/tipe peralatan untuk transportasi sampah dan desain TPA.

Berdasarkan hasil survei awal yang peneliti lakukan pada tanggal 23 Februari 2017 di pemukiman warga masyarakat Kota Ternate dari hasil pengamatan, selama ini sampah dikelola dengan konsep buang begitu saja (open dumping), buang bakar (dengan incenerator atau dibakar begitu saja), gali tutup (sanitary landfill). Ternyata tidak memberikan solusi yang baik, 
apalagi jika pelaksanaanya tidak disiplin. Penyebab banjir di Ternate umumnya sampah organik, plastik atau kaleng- kaleng yang sulit terurai. Sampah-sampah jenis ini juga perlu mendapat perhatian kita untuk di daur ulang. Dalam konteks inilah perlu dicari solusi penanganan sampah kota yang tepat, yang mampu mengeliminir menumpuknya timbunan sampah, sampai mencapai taraf zero waste. Penelitian ini bertujuan untuk mengetahui komposisi sampah rumah tangga di Ternate.

\section{METODE PENELITIAN}

Penelitian ini merupakan penelitian survei dengan menggunakan pendekatan deskriptif kuantitatif dan penelitian pengembangan. Penelitian ini terdiri dari dua jenis penelitian, yaitu (1) penelitian survei dengan menggunakan pendekatan deskritif kualitatif dan (2) penelitian pengembangan untuk menyusun panduan praktikum mata kuliah pendidikan lingkungan. Survei dilakukan untuk mengetahui komposisi sampah sampah organik dan non organik rumah tangga di Kota Ternate. Penelitian ini berlangsung selama dua bulan. Penelitian ini akan dilaksanakan pada 3 (tiga) sentra pemukiman warga di Kota Ternate, yakni di Kelurahan Bastiong di Kecamatan Ternate Selatan, Kelurahan Akehuda di Kecamatan Ternate Utara, dan Kelurahan Gamalama di Kecamatan Ternate Tengah. Variabel penelitian ini adalah komposisi sampah rumah tangga sub variabel, dan indikator diuraikan dalam tabel berikiut.

Tabel 1. Variabel, sub variabel, dan indikator penelitian

\begin{tabular}{|c|c|c|}
\hline Variabel & Sub Variabel & Indikator \\
\hline $\begin{array}{l}\text { 1. Timbulan } \\
\text { sampah rumah } \\
\text { tangga. }\end{array}$ & $\begin{array}{l}\text { a. Timbulan sampah } \\
\text { organik } \\
\text { b. Timbulan sampah } \\
\text { anorganik }\end{array}$ & $\begin{array}{l}\text { Berat (Kg) bahan-bahan berikut: } \\
\text { Anorganik: } \\
\text { a. Kertas koran } \\
\text { b. Kertas HVS putih } \\
\text { c. Kertas Berwarna } \\
\text { d. Kardus/kertas karton } \\
\text { e. Botol kaca } \\
\text { f. Botol/gelas plastik } \\
\text { g. Bungkus snak/kemasan instan lain } \\
\text { h. Tas kresek } \\
\text { i. Bekas mainan } \\
\text { j. Prabotan rumah tangga } \\
\text { k. Gelas/kaca } \\
\text { l. Logam } \\
\text { m. Sampah elektronik } \\
\text { n. Kain dll. } \\
\text { Organik } \\
\text { a. Sisa makanan } \\
\text { b. Sisa potongan sayur \& buah } \\
\text { c. Sampah sapuan halaman }\end{array}$ \\
\hline $\begin{array}{l}\text { 2. Komposisi } \\
\text { sampah rumah } \\
\text { tangga. }\end{array}$ & $\begin{array}{l}\text { a. Komposisi sampah } \\
\text { organik } \\
\text { b. Komposisi sampah } \\
\text { anorganik }\end{array}$ & $\begin{array}{l}\text { Persentase }(\%) \text { berat masing- masisng komponen } \\
\text { yang terdapat dalam buangan padat (anorganik } \\
\text { dan organik. }\end{array}$ \\
\hline $\begin{array}{l}\text { 3. Panduan } \\
\text { praktikum }\end{array}$ & & $\begin{array}{l}\text { Kegiatan I. Sampah organik } \\
\text { Kegiatan II . Sampah anorganik }\end{array}$ \\
\hline
\end{tabular}

Populasi merupakan wilayah generalisasi yang terdiri atas obyek/ subyek yang memiliki kualitas dan karakteristik tertentu yang ditetapkan oleh peneliti untuk dipelajari kemudian 
ditarik kesimpulannya (Sugiyono, 2009). Populasi dalam penelitian ini adalah seluruh rumah tangga di Kelurahan Bastiong, Kelurahan Akehuda, dan Kelurahan Gamalama.

Sampel adalah sebagian jumlah dan karakteristik yang dimiliki oleh populasi tersebut, atau bagian kecil dari anggota populasi yang diambil dengan prosedur tertentu sehingga dapat mewakili populasi (Sugiyono, 2009). Sampel dalam penelitian ini adalah sebagian rumah tangga yang ada di Kelurahan Bastiong, Akehuda, dan Gamalama. Penentuan lokasi sampling atas dasar pertimbangan keterwakilan sebaran wilayah yang mewakili karakter rumah tangga di Kota Ternate. Penentuan jumlah sampel dilakukan dengan metode sampling kuota (non probability sample). Jumlah sampel ditetapkan sebanyak 90 rumah tangga, sehingga masingmasing kelurahan sebanyak 30 rumah tangga. Objek penelitian ini adalah sampah (material buangan padat) yang dikumpulkan dari sampel rumah tangga, baik berupa sampah organik maupun sampah anorganik.

Timbulan sampah diukur dengan cara penimbangan sampah rumah tangga (yang terpilih sebagai sampel rumah tangga) berdasarkan jenisnya, baik pada sampah organik maupun sampah anorganik. Satuan timbulan sampah masing-masing jenis adalah $\mathrm{kg} / \mathrm{orang} / \mathrm{bulan}$. Komposisi sampah dihitung dengan cara menghitung presentase $\mathrm{kg}$ berat setiap jenis sampah atas $\mathrm{kg}$ berat total sampah. Komposisi sampah menghasilkan gambaran distribusi dan persentase (\%) masing-masing komponen yang terdapat dalam suatu kumpulan sampah. Penghitungan komposisi menggunakan data dasar dari pengukuran timbulan.

Alat-alat yang digunakan dalam penelitian ini adalah; timbangan geser, timbangan portable kantong sampah berbahan plastik, skop sampah, masker, sarung tangan, kamera dokumentasi dan alat tulis (pensil, pulpen, papan alas menulis, dan block note)

Teknik pengumpulan data sampah sebagai berikut:

1. Sampah dikumpulkan dari rumah tangga sampel menggunakan kantong sampah.

2. Pengumpulan sampah dilakukan pada minggu 1 dan 4, dilakukan pukul 07.00 pagi hari.

3. Kantong sampah yang berisi sampah diberi etiket gantung yang mencantumkan: (1) nomor kode responden, (2) kelurahan, serta (3) tanggal pengumpulan.

4. Sampah yang terkumpul dalam wadah kantong sampah dibawa ke tempat pengumpulan sampah untuk dipilah-dipilah berdasarkan komponen sampah, kemudian dilakukan penimbangan berat setiap jenis/kompoen sampah.

5. Hasil penimbangan komponen sampah setiap rumah tangga dicatat dalam form data sampah.

\section{Teknik Analisa Data}

Penelitian ini menggunakan teknik analisis data dengan pemaparan secara kuantitatif. Pemaparan data meliputi: (1) data berat $(\mathrm{kg})$ setiap komponen yang diestimasi ke satuan $\mathrm{kg} /$ bulan/orang, dan (2) persentasi berat tiap kompon atas berat total sampah.

\section{HASIL PENELITIAN}

Berdasarkan hasil analisis data sampah rumah tangga pada 60 rumah tangga, terdapat komposisi sampah. Komposisi sampah terdiri dari berbagai macam sampah yang diperoleh dapat dilihat pada tabel berikut :

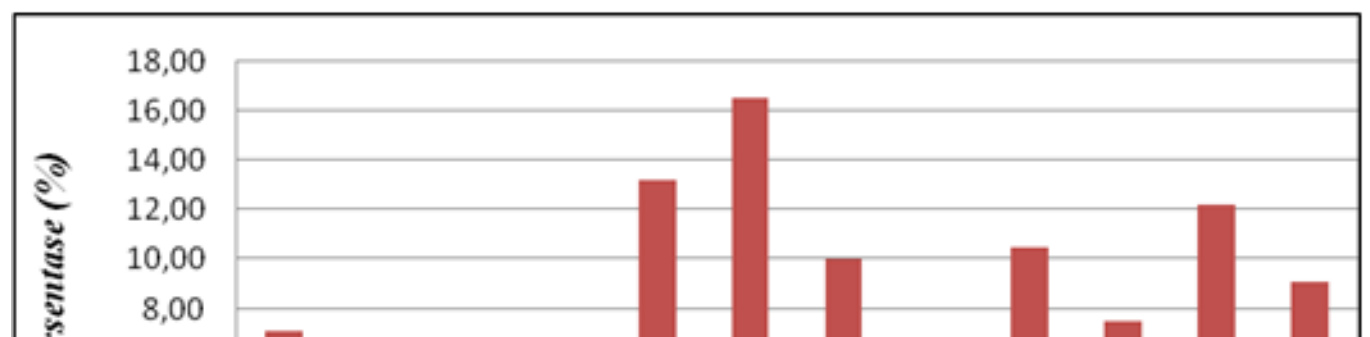




\section{Gambar 1. Grafik Komposisi Sampah Rumah Tangga}

Komposisi sampah yang dihasilkan dari 60 rumah tangga bervariasi. Pada jenis sampah kertas koran komposisinya mencapai $7,1 \%$, kertas HVS putih 2,78\%, kardus/kertas karton 3,92\%, botol kaca 6,37\%, botol/gelas plastik 13,19\%, bungkus snak/kemasan instan 16,53\%, tas kresek 10,03\%, bekas mainan $0,69 \%$, bungkus rokok $10,5 \%$, pampers $7,51 \%$, sisa makanan $12,24 \%$ dan sisa potongan sayur dan buah 9,12\%. Hal ini menunjukan bahwa komposisi sampah yang dihasilkan oleh responden yang ada cukup tinggi.

Hasil penelitian menunjukkan bahwa timbulan sampat berbeda pada tiap rumah tangga. Perbedaan besar timbulan sampah di setiap rumah tangga ini dapat disebabkan karena perbedaan tingkat ekonomi, gaya hidup, pendidikan dan mobilitas penduduk sehingga jenis sampah yang dihasilkan bermacam-macam. Timbulan sampah dalam rumah tangga juga dipengaruhi oleh jumlah keluarga, semakin banyak jumlah keluarga maka semakin banyak pula kebutuhan sehingga meningkatnya sampah yang dihasilkan. Menurut Damanhuri, 2004 faktor yang mempengaruhi timbulan sampah yaitu jumlah penduduk dan tingkat pertumbuhannya, tingkat hidup, perbedaan musim, cara hidup dan mobilitas penduduk dan cara penanganan makanannya.

Pada hasil penelitian sampah jenis bungkus snak/kemasan instan, botol/gelas plastik dan sisa makanan lebih dominan, karena sampah jenis ini merupakan kebutuhan pokok yang harus dipenuhi oleh setiap rumah tangga. Makanan dan minuman yang dikonsumsi sehari-hari dikemas dalam kemasan instan, kemudian botol/gelas plastik sering ditemukan dalam setiap rumah tangga untuk dipakai minum, sedangkan makanan merupakan kebutuhan sehari-hari pada tiap rumah tangga. Pada tiap rumah tangga terdapat sisa sisa makanan yang sudah tidak layak dimakan, sehingga menjadi sampah yang bertumpukan. Hal ini menyebabkan lingkungan disekitar tercemar oleh udara sehingga menimbulkan bau yang tak enak.

Timbulan sampah juga dilihat dari kebutuhan makanan untuk sehari-hari dapat dipenuhi berbagai cara. Cara-cara yang dilakukan meliputi memasak, membeli makanan cepat saji,catering atau lainnya. Pemenuhan kebutuhan makanan ini akan mempengaruhi timbulan dan jenis sampah yang dihasilkan. Sebuah penelitian diperoleh rata-rata timbulan sampah 
rumah tangga $0,35 \mathrm{~kg} /$ hari, hasil rata-rata tersebut dilihat dari pendapatan responden (Damanhuri, 2006).

Faktor yang mempengaruhi fenomena timbulan sampah rumah tangga yang dihasilkan, diduga disebabkan karena waktu yang dihabiskan oleh penghuni rumah untuk tinggal di dalam rumah. Intensitas waktu penghuni didalam rumah memiliki aktivitas tertentu yang akan dapat menghasilkan sampah. Semakin lama waktu yang dihabiska di dalam rumah semakin banyak pula sampah yang dihasilkan. Becker (1996) dalam Febrero \& Schwartz (2000), mengemukakan teori alokasi waktu dengan perbedaan kegiatan yaitu bahwa total waktu dibedakan atas waktu produktif yang benar-benar digunakan untuk bekerja di luar rumah (productiv workin time) dan waktu produktif yang digunakan untuk santai di rumah atau dengan melakukan aktivitas lain di dalam rumah (work at home or not work). Apabila teori Becker tersebut dikaitkan dengan timbulan sampah , maka penggunaan waktu produktif untuk bekerja di luar atau di dalam rumah dapat mempengaruhi timbulan sampah yang akan dihasilkan.

Seperti yang telah disebutkan sebelumnya, jenis pekerjaan seseorang dapat menentukan lamanya ia berada di luar atau di dalam rumah. Misalkan seseorang bekerja sebagai PNS yang memiliki cukup kesibukan sehingga mengharuskan ia berada di luar rumah lebih lama daripada berada di dalam rumah. Oleh sebab itu, jumlah sampah yang dihasilkan lebih sedikit dibanding seseorang yang sepanjang hari tinggal di dalam rumah. Pada data hasil pengamatan, responden ada yang memiliki pekerjaan sebagai pedagang atau lebih tepatnya sebagai pedagang kaki lima, sehingga sampah sisa-sisa belanjaan tersebut akan dapat mempengaruhi tingginya berat sampah yang dihasilkan.

Menurut hasil pengamatan langsung, orang-orang yang menghabiskan banyak waktu di dalam rumah adalah orang yang sudah tidak aktif bekerja diluar karena pensiun, ibu rumah tangga, bayi, dan pembantu rumah tangga. Aktivitas mereka didalam rumah sepanjang hari tentu saja akan lebih banyak menghasilkan sampah. Sehingga sampel sampah yang didapatkan pada sampah rumah tangga salah satunya yaitu pampers.

Urutan komposisi sampah dari jumlah paling besar hingga terkecil yaitu bungkus snak/kemasan instan, botol/gelas plastik, sisa makanan, bungkus rokok, tas kresek, sisa potongan sayur dan buah, pampers, kertas koran, botol kaca, kardus/kertas karton, kertas HVS putih dan bekas mainan. Hasil penelitian menunjukan bahwa komposisi sampah terbanyak yaitu bungkus snak/kemasan instan, kemudian botol/gelas plastik dan sisa makanan. Hal ini menunjukan bahwa rata- rata responden lebih sering membeli makanan dan minuman dalam kemasan instan, karena faktor dalam penghuni rumah responden rata-rata memiliki anak-anak yang suka dengan makanan-makanan snak. Hal ini yang membuat komposisi bungkus snak/kemasan instan lebih dominan. Saat ini kebutuhan akan makanan instan bagi penghuni rumah sudah biasa, karena rata-rata responden cenderung mengkonsumsi makanan yang instan. Pada botol/gelas plastik dan sisa makanan komposisinya yaitu, 13,19\% dan 12,24\%. Sampah jenis ini dominan karena pada tiap rumah tangga sudah menjadi kebutuhan yang wajib. Setiap hari membutuhkan makan dan minum sehingga sisa-sisa minum dan makan tersebut dibuang begitu saja. Oleh sebab itu sampah jenis inilah yang sangat dominan pada rumah tangga.

Komposisi sampah bekas mainan dan kertas HVS putih yang paling sedikit persemtasenya,. Hal ini menunjukan bahwa, responden tidak terlalu memiliki bekas mainan karena faktor responden lebih sering membelikan anak-anak makanan dan jajanan lainnya dibandingkan dengan mainan. Sehingga komposisi bekas mainan lebih sedikit persentasenya. Saat ini kebutuhan akan mainan untuk anak-anak tidak terlalu dipenuhi oleh orangtuanya, karena cukup dengan handphone 
anak-anak sudah bisa bermain/terhibur.Sedangkan kertas HVS putih tidak terlalu ditemukan pada saat penelitian, karena rata- rata pada tiap rumah tangga kertas HVS putih digunakan sebagai alat tulis juga sebagai pengalas lemari, rak cuci piring.

Tipikal komposisi sampah rumah tangga untuk negara dengan pendapatan rendah ini adalah jenis sampah sisa makanan (40-85\%), sampah kertas (1-10\%), sampah plastik,tekstil,karet, kayu dan halaman (1-5\%), dan kaca (1-10\%). Informasi tentang komposisi sampah dibutuhkan untuk penentuan luas areal tempat pembuangan akhir (TPA) dan pengolahan sampah secara biologi composting. Komposisi sampah di bagi kedalam kategori sampah terdekomposisi (Pd) dan sampah yang tidak terdekomposisi (Tchobanoglous,1993).

Berdasarkan hasil pengukuran komposisi sampah, diketahui bahwa banyak sampah yang dihasilkan, sehingga diperlukan cara untuk mengurangi sampah tersebut dengan cara untuk pemanfaatan kembali. Contoh pemanfaatan kembali ialah dengan memanfaatkan barang bekas untuk fungsi sama atau berbeda seperti misalnya botol sirup bekas dijadikan tempat air, tempat cat dijadikan bak sampah dan lain-lain. Selain itu pemanfaatan dapat dilakukan dengan cara menjual barang bekas ke pihak-pihak yang dapat memanfaatkannya (penadah) sehingga warga dapat mendapatkan keuntungan finansial dari hasil penjualan tersebut.

Potensi sampah dapat dipermudahkan yaitu dengan cara memanfaatkan kembali, maka perlu dilakukan proses pemilahan sampah terlebih dahulu. Sebaiknya sampah dikumpulkan berdasarkan jenisnya dan dipisahkan pada tempat sampah yang berbeda, sehingga sampah organik tidak akan mengotori sampah anorganik yang masih dapat dimanfaatkan kembali. Namun hal ini mungkin akan sulit diterapkan karena rata-rata responden tidak pernah melakukan pemilahan sampah sebelumnya dirumah.

Pengurangan sampah merupakan upaya yang dilakukan terhadap maerial sampah berupa pemanfaatan kembali, pembatasan timbulan dan pendaur ulangan sampah. Cunnigham (2004) dalam teorinya mengatakan bahwa tahap pengelolaan sampah modern terdiri dari 3R (Reduce,Reuse,Recycle) sebelum akhirnya dimusnahkan atau dihancurkan. Berdasarkan teori tersebut penulis mengklaifikasikan tiga upaya pengurangan sampah yang dilakukan di Kota Ternate yaitu 3R (Reduce,Reuse,Recycle).

Menurut Suyoto (2008), tindakan yang dapat dilakukan berkaitan dengan reduce yaitu hindari pemakaian dan pembelian produk yang menghasilkan sampah dalam jumlah besar, gunakan kembali wadah/kemasan untuk fungsi yang sama atau fungsi yang lain, jual atau berikan sampah yang terpilah kepada pihak yang memerlukan, membeli barang dengan kemasan yang dapat di daur ulang dan membawa kantong/tas belanja sendiri ketika berbelanja.

Prinsip reuse dilakukan dengan cara sebisa mungkin memilih barang-barang yang bisa dipakai kembali. Dan juga menghindari pemakaian barang-barang yang hanya sekali pakai. Hal ini dapat memperpanjang waktu pemakaian barang sebelum menjadi sampah. Gunakan produk yang dapat diisi ulang, plastik kresek digunakan untuk tempat sampah, kertas koran digunakan untuk pembungkus dan potongan kain digunakan untuk lap,keset dan lain-lain.

\section{KESIMPULAN}

Berdasarkan hasil penelitian dapat disimpulkan bahwa komposisi sampah rumah tangga di Kota Ternate yaitu kertas koran 7,1\%, kertas HVS putih 2,78\% kardus / kertas karton 3,92\%, botol kaca $6,37 \%$, botol/gelas plastik 13,19\%, bungkus snak/kemasan instan 16,53\%, tas kresek 10,03\%, 
bekas mainan $0,69 \%$, bungkus rokok $10,5 \%$, pampers $7,51 \%$, sisa makanan $12,24 \%$ dan sisa potongan sayur dan buah $9,12 \%$.

\section{DAFTAR PUSTAKA}

Akbar, Michael M. Rengkung, Fella Warouw. 2014. Analisis Sistem Persampahan di Kota Ternate. Jurnal Sabua. ISSN 2085-7020. Volume 6 (3) November 2014, p 351-362.

Azkha, Nizwardi. 2006. Analisis Timbulan, Komposisi dan Karakteristik Sampah di Kota Padang. Jurnal Kesehatan Masyarakat, September 2006, I (1).

Bichi M. H. and Amatobi D.A. 2013. Characterization of Household Solid Wastes Generated in Sabon-Gari Area of Kano in Northern Nigeria. American Journal of Research Communication. Vol 1 (4).

Biro Pusat Statistik (BPS) Kota Ternate. Kota Ternate dalam Angka tahun 2016.

Chandra, Budiman. 2006. Pengantar Kesehatan Lingkungan. EGC. Jakarta

Cunningham, W.P. and M. A. Cunningham and (2004) Principles of Environmental Science, Second Edition. McGraw-Hill Co., Dubuque,IA.

Dainur. 1995. Materi-Materi Pokok Ilmu Kesehatan Masyarakat. Widya Medika. Jakarta.

Damanhuri E, Padmi T. 2004. Timbulan Sampah untuk Kota Sedang dan Kecil di Indonesia. Penerbit TL-ITB. Bandung.

Farikhayati. 2009. Pengembangan Buku Petunjuk Praktikum Kimia untuk SMP/MTs Kelas VII Berdasarkan Kurikulum Tingkat Satuan Pendidikan (KTSP) (Skripsi). Yogyakarta: Fakultas Sains dan Teknologi Universitas Islam Negeri Sunan Kalijaga.

Gelbert, M., et.al. 2010. Konsep Pendidikan Lingkungan Hidup dan "Wall Chart", Buku Panduan Pendidikan Lingkungan Hidup, PPPGT/ VEDC. Malang.

Hidayat, N., M.C. Padaga, dan S. Suhartini. 2006. Mikrobiologi Industri.

Penerbit Andi. Yogyakarta

Ibrahim,2001. Model Pengembangan Perangkat Pembelajaran Menurut Jerold E. Kemp. Dan Thiagarajan. Surabya: Unipress Unifersitas Negeri surabaya.

Ibrahim, 2001. Model Pengembangan Pembelajaran Menurut Jerold E. Kemp. Dan Thiagarajan. Surabaya: Unipress Universitas Negara Surabaya

Krisnawati, H., M. Kallio, dan M. Kanninen. 2011. Aleurites moluccana (L.) Willd. Ekologi, Silvikultur dan Produktivitas. CIFOR. Bogor.

Mbeng L.O., Paul S. Phillips, and Roy Fairweather. 2012. Waste Characterization as an Element of Household Waste Management Operations: A Case Study in Limbe, Cameroon. The Open Waste Management Journal, ISSN 1876-4002, 5, 49-58.

SK SNI 19-3964-1994. Metode Pengambilan dan Pengukuran Contoh Timbulan, Komposisi Sampah Perkotaan. Departemen Pekerjaan Umum. Bandung.

Tchobanoglous, G., Teisen H., Eliasen, R, 2013, Integrated Solid Waste Manajemen, Mc.Graw Hill : Kogakusha, Ltd. New York.

Widiarti, Ika Wahyuning. 2012. Pengelolaan Sampah Berbasis "Zero Waste" Skala Rumah Tangga Secara Mandiri. Jurnal Sains dan Teknologi Lingkungan. ISSN 2085-1227. Volume 4 ( 2), Juni 2012, Halaman 101-113 Program Studi Teknik Lingkungan Fakultas Teknologi Mineral Universitas Pembangunan Veteran Yogyakarta.

Widyatmoko dan Sintorini Moerdjoko, 2002, Menghindari, Mengolah dan Menyingkirkan Sampah. Abadi Tandur, Jakarta.

Widiyatmoko H., Pramiati Purwaningrum, Febrina Putri Arum. 2014. Analisis Karakteristik Sampah Plastik di Permukiman Kecamatan Tebet dan Alternatif Pengolahannya. Jurnal Teknik Lingkungan, Vol. 7 No. 1, 24 - 33., Universitas Trisakti, Indonesia. 
Zubair A, Nogard S. Mahendra \& Asrini. 2011. Studi Karakteristik Sampah Rumah Tangga di Kota Madya Makassar dan Prospek Pengembangan-nya. Prosiding Hasil Penelitian. Fakultas Teknik Universitas Hasanuddin.

Zulkifli, A 2014. Dasar-Dasar Ilmu Lingkungan. Jakarta; Salemba Teknika. 